Review

\title{
Regulatory signal mechanisms of systemic inflammation in respiratory pathology
}

\author{
Tatyana P. Novgorodtseva, Tatyana A. Gvozdenko, Tatyana I. Vitkina, Yuliya K. Denisenko, \\ Marina V. Antonyuk, Vera V. Knyshova
}

Vladivostok Branch of Far Eastern Scientific Centre of Physiology and Pathology of Respiration - Institute of Medical Climatology and Rehabilitative Treatment, Vladivostok, Russia

Received 16 May 2018, Revised 12 October 2018, Accepted 17 October 2018

(C) 2018, Novgorodtseva T.P., Gvozdenko T.A., Vitkina T.I., Denisenko Y.K., Antonyuk M.V., Knyshova V.V.

(C) 2018, Russian Open Medical Journal

Abstract: The paper presents data from literature and own studies of regulatory mechanisms of systemic inflammatory response in chronic obstructive pulmonary disease (COPD) and asthma. At the heart of the formation of a systemic inflammatory reaction is a complex of disturbances in the regulation of intra- and intercellular signaling. Etiopathogenesis of COPD and asthma differs, but immune disorders and regulatory mechanisms of systemic inflammation in the diseases have common characteristics. There are multi-type Th immune responses in both COPD and asthma, the nature of which depends on severity or control of the disease. Mixed phenotypes Th1/Th17 and Th2/Th17 appear and are followed by the formation of Th17 type of immune response associated with a worsening of the disease. General mechanisms of maintenance of systemic inflammation in the diseases have been found. These include hyperproduction of cytotoxic eicosanoids, decreased expression of CB2 receptors, the formation of mitochondrial dysfunction due to violations of the fatty acid composition of the organelle, increased synthesis of nitric oxide. The authors presented a new view on the role of immune, lipoxygenase, nitroxidergic, endocannabinoid signaling systems in the formation of systemic inflammation in chronic respiratory diseases.

Keywords: systemic inflammatory reaction, signal systems, respiratory diseases

Cite as Novgorodtseva TP, Gvozdenko TA, Vitkina TI, Denisenko YK, Antonyuk MV, Knyshova VV. Regulatory signal mechanisms of systemic inflammation in respiratory pathology. Russian Open Medical Journal 2019; 8: e0106.

Correspondence to Vera V. Knyshova. Address: Russkaya str. 73g, Vladivostok, 690105, Russia. E-mail: v.knyshova@mail.ru. Phone: +7(423)2788-202.

At present time, the pathogenesis of various diseases is considered in terms of typical pathological processes. One of the main typical pathological processes is inflammation, a universal complex of genetically programmed reactions to any phologogenic agents. Pathophysiological changes in chronic respiratory diseases are caused by local inflammation in the airways that results in bronchial obstruction, destructive processes in the lung parenchyma, remodeling of the lung tissue and disruption of gas exchange [1-3]. The development of local inflammation in chronic respiratory diseases is followed by the formation of a systemic inflammatory process, which is a basis for subsequent pathophysiological changes and systemic effects leading to extrapulmonary manifestations of the disease [4-6]. The concept of "systemic inflammation» is relatively new. Modern molecular biology has uncovered many mechanisms of humoral and cellular responses characterizing systemic inflammation (cytokinemia, oxidative stress, reactivity of immunocompetent cells, etc.) At the same time, factors that initiate the systemic inflammatory reaction remain unclear. The role of cytokines, eicosanoids, enzymes and receptors of signaling systems in many chronic diseases is known [713]. There are a few studies on the involvement of the endocannabinoid system in the regulation of the immune response [14-15]. However, the functions and interactions of the cytokine, lipoxygenase, nitroxidergic, endocannabinoid signaling systems in chronic respiratory diseases are incompletely studied.

A large number of inflammatory mediators are involved in the control of the systemic inflammatory process. The main defect underlying the development of a systemic inflammatory reaction is an impairment of the ability of cells to synthesize various signaling molecules, such as cytokines, lipid mediators (eicosanoids and endocannabinoids), nitric oxide (NO), carbon monoxide and etc. Signal molecules are unique regulators of intra- and intersystem interactions. They provide the concerted action of the immune, endocrine and nervous systems under normal conditions and respond to pathological impact.

Cytokines, their soluble and membrane receptors play a key role in the inflammatory process. They act as mediators of the immune system regulating the strength and duration of the immune response and inflammatory process. Regulatory mechanisms, which are mediated by the production of anti-inflammatory cytokines and soluble inhibitors of pro-inflammatory cytokines, are activated to protect against excess manifestations of systemic inflammation. These mechanisms initiate the development of deep immunosuppression that is clinically manifested by chronicity, disability of repair processes and the disease worsening [16-17]. 


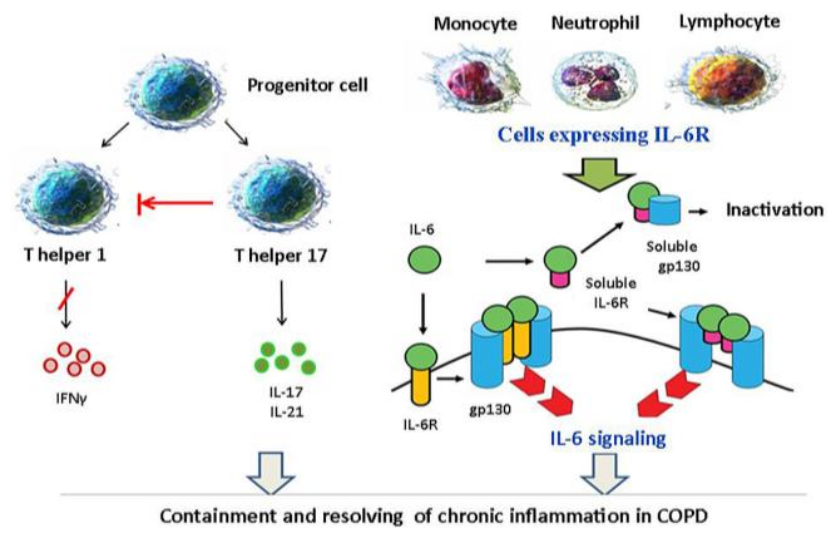

Figure 1. Immune mechanisms of COPD progression.

The definition of immunological constitution can allow clinicians to predict the predisposition to certain types of immune response, immune adaptation and various types of immunopathology in respiratory diseases (allergy, autoimmune processes and immunodeficiencies). Active subpopulations of $\mathrm{CD} 4^{+}$ $T$ cells play a significant role in the regulation and the development of immunopathology [18]. This aspect of subpopulation activity is manifested under conditions of their imbalance: the predominance of Th2 cell differentiation underlie the predisposition to allergy, the expansion in the number of Th17 cells increases the risk of autoimmune processes. The propensity to different types of immune response is largerly genetically determined [19]. The analisys of the subpopulation of $\mathrm{CD}^{+}$ regulatory cells in respiratory diseases make it possible to evaluate the capability of respiratory organs to adapt to increasing exogenous and endogenous load and detect the ability of an organism to properly control chronic systemic inflammation.

The study of the immune mechanisms of the progression of chronic obstructive pulmonary disease (COPD) has showed that in patients with mild COPD pathology mainly develop according to Th1 type of immune response, in some cases Th17 phenotype is detected. In moderate COPD Th1/Th17 type is formed, as COPD progresses the immune response is switched to the Th17 phenotype. A variety of forms of immune response is achieved through activation of different effector cells: Th1 immune response is associated with activation of macrophages and IFN- $\gamma$ production; deviation to Th17 immune response is characterized by activation of neutrophils, epithelial cells and synthesis of IL-17, IL-21. Cytokines, which are produced by Th17 cells as COPD develops, inhibit the differentiation of Th1 clones and form independent immunoregulatory pathway that supress the function of Th1 lymphocytes [20-22].

In recent years, a large number of scientific publications have been devoted to the study of the role of interleukin-6 (IL-6) in the development of COPD [23]. According to the studies, IL-6 level greatly increases in blood plasma in COPD. It indicates the significance of this cytokine in COPD pathophysiology. IL-6 possesses both pro- and anti-inflammatory activities and plays an important role in the differentiation of T-helper cells, which are the main component of the acquired immune response and are involved in the processes of cell proliferation and apoptosis [24]. IL-6 induces the expression of various genes, such as the acute phase protein genes, transcription factor genes, and genes of various proteins (including suppressors of JAK/STAT pathway) that provide the proliferation, survival and functions of many leukocyte populations [25]. Currently, IL-6 is considered as an important mediator of the immune response that directly acts on $\mathrm{CD} 4^{+} \mathrm{T}$ cells and determines their effector functions. IL-6 plays a key role in switching of the immune response from the tolerant state supported by Treg to the active inflammatory state mediated by Th17. Vitkina T.I. et al. have shown that COPD progression is accompanied by an increase in the number of immunocompetent cells expressing IL-6 receptor (IL-6R). These data indicate the importance of classical IL- 6 signaling in immunoregulation. The classical IL-6 signaling pathway mediates anti-inflammatory effects, which makes IL-6R a potential target for COPD therapy [26-27]. It is possible that the deviation to Th17 response along with the overexpression of IL-6R in chronic respiratory diseases plays a compensatory role in containment of the pro-inflammatory mechanisms of immunoregulation (Figure 1).

According to modern views, $\mathrm{CD}^{+} \mathrm{T}$ cells play a decisive role in asthma pathogenesis [28]. They prevail among lymphocytes infiltrating the respiratory tract of patients with asthma. $\mathrm{CD}^{+} \mathrm{T}$ cells can quickly clone in response to certain stimuli. $\mathrm{CD}^{+} \mathrm{T}$ cells act on other cells and initiate in them a cascade of inflammatory mediators by releasing cytokines. The authors have revealed a multi-type Th immune response in asthma patients, the nature of which depends on disease control and characteristics of the infectious and allergic status. It has been established three Thdependent types of immune response in patients with controlled asthma in remission: Th1, Th2 and Th1/Th2. Mixed Th1/Th2 phenotype is an indicator of worsening of controlled asthma. This phenotype is formed due to overlap of Th1 response and allergenspecific Th2 response and is associated with the presence of chronic foci of bacterial and viral infection. Th2/Th17, Th1/Th17 and Th17 types of immune response have been identified in patients with partially controlled asthma. Th17 phenotype is also characteristic for patients with uncontrolled asthma with mixed sensitization to allergens, obesity, chronic bacterial and herpetic infection, exacerbations more than 4-6 times per year [29-31]. The activation of Th17 phenotype promotes the disease prolongation, which is associated with the involvement of neutrophilic granulocytes in the inflammatory process.

A cascade of cytokine-mediated regulatory disorders is accompanied by the activation of eicosanoid synthesis that is involved in vasoconstriction, aggregation and chemotaxis of leukocytes. Prostaglandins (PG), thromboxanes (TX) and leukotrienes (LT), which are the main mediators of inflammatory response at its initial stage, and pro-resolving mediators (resolvins, maresins, protectins, lipoxins), recently discovered biologically active substances, play a key regulatory role (see Figure 1 in [11]) [9-11, 32-33].

The major substrates for eicosanoid synthesis are arachidonic acid (AA, 20:4n-6), metabolites of which have a high proinflammatory, bronchoconstrictor and vasoconstrictor activities, and n-3 fatty acids (FAs) - eicosapentaenoic acid (EPA, 20:5n-3) and docosahexaenoic acid (DHA, 22:6n-3). Eicosanoids formed from these FAs exhibit either weak pro-inflammatory properties or anti-inflammatory, vasodilator and antithrombotic effects.

Modification of the FA profile in membrane lipids manifests not only a change in the eicosanoid synthesis. It is the cause of the disruption of physical and chemical properties of cell membranes a decrease in fluidity, receptor expression, permeability and transport of substances [34]. Many functions of 
immunocompetent cells (secretion, chemotaxis, sensitivity to microorganisms) depend on lipid composition of membrane and, consequently, its fluidity [35-36]. It can be assumed that the modification of FA composition of cell mebranes is an important factor in the disturbance of the regulatory mechanisms of inflammatory process, the development and progression of respiratory diseases. There are several studies indicating that chronic inflammation is associated with significant changes in FA composition of cell mebranes. Similar changes in the quantitative and qualitative characteristics of unesterified FAs in blood plasma have been observed in patients with asthma and COPD: a decrease in the proportion of saturated FAs (SFAs) against the background of an increase in the relative level of precursors and metabolites of AA. An increase in the proportion of SFAs and AA and depletion of EPA pool in the erythrocyte membrane have been found in asthma and COPD [37-39]. The accumulation of SFAs in a membrane leads to a decrease in its fluidity and the activity of membrane-bound enzymes, increasing the risk of membrane destruction and cell death. An inflammatory process is maintained in asthma and COPD even in the stage of partial and complete remission of the disease. It is supported by a high concentration of $n-6$ polyunsaturated FA (PUFAs) and hyperproduction of cytotoxic eicosanoids. It is known that levels of TXB2 and LTB4 in blood of patients with respiratory pathology is increased. Moreover, patients with controlled asthma have a more pronounced increase in LTB4 level. The hyperproduction of cytotoxic eicosanoids has been noted against a background of increased expression of TNF- $\alpha$. Thus, the run of chronic inflammation during remission in patients with COPD and asthma is mediated by intensive production of pro-inflammatory and bronchoconstrictor mediators [38-39].

The modification of FA composition in blood plasma and erythrocyte membrane, the disruption of the synthesis of oxygenase derivatives of FAs in respiratory diseases testify to the importance of FAs and their metabolites in immune and metabolic mechanisms of the regulation of the systemic inflammatory reaction. PUFAs are precursors for synthesis of potent cellular bioregulators - eicosanoids, proresolvins. Eicosanoids locally regulate functions of the endothelium and smooth muscle cells, vasodilator reaction, platelet aggregation, microcirculation and inflammation. It can be concluded that the maintenance of systemic chronic inflammation in respiratory diseases is carried out by biologically active metabolites of PUFAs - pro-inflammatory eicosanoids. Despite the difference in the immunological mechanisms regulating systemic inflammation, the development of asthma and COPD is associated with unidirectional changes in the FA composition.

FA composition of mitochondrial membranes also undergoes substantial reorganization in respiratory diseases [40-43]. Moreover, the modification of FA composition of mitochondrial membranes is associated with the disease severity. As COPD progresses, the deficiency of $n-3$ PUFAs is aggravated against the background of an increase in the proportion of some n- 6 PUFAs $(20: 4 n-6,22: 4 n-6)[40,42]$. Patients with controlled asthma exhibite decreased pool of the majority of SFAs $(12: 0,14: 0,18: 0$, 22:0) and some PUFAs (20:4n-6, 22:4n-6, 20:5n-3, 22:5n-3) in mitochondrial membranes. Patients with partially controlled asthma have significant deficiency of $n-3$ and $n-6$ PUFAs against the background of accumulation of SFAs $(14: 0,18: 0)$ and monoene FAs $(16: 1 n-9,18: 1 n-9)$ in mitochondrial membranes [43]. A decrease in PUFA pool in the mitochondrial membrane with asthma progression is a logical phenomenon, since pharmacological control over immune mechanisms, including the synthesis of eicosanoids, gets complicated in partially controlled BA.

Structural and functional changes in mitochondria in patients with COPD and asthma indicate violations of the energy metabolism, membrane permeability and transport of substances, and are signs of the formation of mitochondrial dysfunction [44]. All these changes determine the hypoxia development and cell death by apoptosis. Cellular hypoxia leads to destructive processes in the key structural components of the respiratory system - the mucosa of the bronchial pathways, and create conditions for the formation of the chronic obstruction. The number of studies have demonstrated that the mitochondrial dysfunction, which is a result of a violation of FA composition of mitochondrial membranes, makes a significant contribution to the progression of chronic respiratory diseases.

The endocannabinoid system occupies a special place among the regulatory mechanisms of the inflammatory process. It is a universal signal system that performs important functions: regulate of the energy metabolism and the metabolism of carbohydrates and lipids, participate in the immune response. The endocannabinoid system includes cannabinoids (lipid compounds that are metabolites of AA - anandamide and 2arachidonoylglycerol), their receptors type 1 and 2 (CB1 and CB2), which are widely expressed at the surface of cells of the brain and spinal cord, macrophages, neutrophils and lymphocytes, the enzymes of synthesis and decomposition (see Figure 1 in [47]) [14, 45-47]. Cells synthesize different molecular species of endogenous cannabinoids. Endogenous anandamide stimulates the secretion of AA and its metabolites. This ability of endogenous cannabinoids to influence on the metabolism of AA play a certain role in the realization of immune response $[14,48]$. Cannabinoid receptors 2 type (CB2) are localized mainly on the immune cells and are able to regulate the level of inflammatory mediators, limit their releasing, control the inflammatory process at the stage of physiological protection. After interacting with $A A$ derivatives $C B 2$ receptors impact on the differentiation and activation of immunocompetent cells, the production of pro-inflammatory cytokines and chemokines.

Under normal conditions increased expression of CB2 receptor maintain the physiological balance between synthesis of proinflammatory mediators and synthesis anti-inflammatory ones. A decrease in $\mathrm{CB} 2$ receptor expression triggers limiting the functions of the endocannabinoid system, that causes the activation of the immune system $[45,49-51]$.

The results of the study of the integration of the immune and endocannabinoid systems in COPD patients have indicated that the percentage of mononuclear leukocytes expressing surface differentiation antigen to the CB2 receptor depends on the persistence of the pathological process [51-52]. At the present time, it is known that several signaling mechanisms that regulate and control the reactivity of the immune system through $\mathrm{CB} 2$ receptors: the inhibition of adenylate cyclase and the reduction of the production of cyclic adenosine monophosphate (cAMP); the blocking of the expression of nuclear transcription factor triggering the activation of the genes of pro-inflammatory cytokines (NF-kB); the suppression of mitogen-activated proteins (MAPs). Thus, the endocannabinoid system regulates the expression of inflammatory mediators through the limitation of the activation of NF-KB, MAPkinase and CAMP signaling pathways $[8,51]$. Hypercytokinemia 
observed in patients with COPD in a series of studies agrees with a violation of $\mathrm{CB} 2$ receptor expression. As the disease worsens, the number of immune cells expressing CB2 receptor decreases, imbalance in the production of cytokines increases and potentiates the development of chronic inflammation. The reduction of CB2 receptor expression in mild COPD is accompanied by an increase in the level of pro-inflammatory cytokines (TNF- $\alpha$, bFGF, TGF- $\beta$ ), which is compensated by the normal concentration of cytokines with immunosuppressive activity (IL-8). The inhibition of $\mathrm{CB} 2$ receptor expression in moderate COPD is characterized by an increase in TNF- $\alpha$, bFGF, TGF- $\beta$ levels and the reduction of IL- 8 level. Taking into account that an decrease in $\mathrm{CB} 2$ receptor expression is associated with a violation of the regulation of the immune response and the development of chronic systemic inflammation, it can be concluded that the integration of the immune and endocannabinoid systems under conditions of inflammation is reciprocal: CB2 receptor expression by immunocompetent cells is inhibited, while simultaneously activating the synthesis of pro-inflammatory cytokines [51, 52]. Consequently, the blockade of $\mathrm{CB} 2$ receptor expression has a great importance for the regulation of the inflammatory response. Understanding these mechanisms will help us to develop technologies for the selective regulation of the inflammatory process.

The results described above have been confirmed by E.G. Lobanova. et al. They studed the impact of various doses of the synthetic ligands of cannabinoid receptor WIN-55,212-2 and anandamide on the reactivity of immunocompetent cells and the synthesis of eicosanoids $[51,53]$. The synthetic cannabinoids have been shown under in vitro conditions to inhibit the ability of immune cells to express IL-2, IL-8, TNF- $\alpha$, while exhibiting a dosedependent immunosuppressive effect. It has also been established that WIN-55,212-2 and anandamide dose-dependently block the lipoxygenase pathway of the production of a pro-inflammatory eicosanoid, leukotriene B4, without affecting thromboxane B2 synthesis. The inhibition of leukotriene B4 synthesis has a suppressor effect on the activity of the immune system. The revealed selective effect of WIN 55,212-2 and anandamide on the expression of oxylipins can be used to develop pharmaceutical preparations with a targeted immunomodulatory action.

The second messengers of the nitroxidergic system are an important part in the regulation of the immune and metabolic response of a cell and the inflammatory processes. The signaling system has universal mechanisms of the regulation of various physiological and pathophysiological processes in the body and include a complex of structures that are capable to rapidly generate a powerful auto- and paracrine mediator, NO, under action of a specific group of enzymes [54-55]. NO is a member of a new class of signaling molecules and serves as a regulator of prooxidant, antioxidant and immune processes.

The study of systemic NO level has showed that the response of the nitroxidergic system is the same in the respiratory diseases associated with airflow limitation and inflammation. NO blood level equally increased in asthma, COPD and comorbid state of these pathology. At the same time, the increase in NO level directly correlated with the severity of the pathological process [56]. This evidence suggests that regulatory pathways of the nitroxidergic system are uniform in the chronic inflammatory respiratory diseases [54]. The increased NO production in pulmonary diseases is a compensatory mechanism aimed at maintaining vascular tone, protection against platelet aggregation, reducing spasm of smooth muscles of the respiratory tract, increasing resistance to bronchoconstrictors and bactericidal action. However, the activation of the inducible form of NO synthase in inflammation can lead to a sharp increase in NO production by cells of the respiratory system. A high NO level in this case contributes to the intensification of inflammatory processes and damage to the airways in COPD and asthma. The increased $\mathrm{NO}$ level is of particular importance in the pathogenesis of COPD, because active forms of nitrogen intensifies oxidative stress, which is one of the main factors for the disease progression. The results of researchs have indicated that the nitroxidergic system is key to the development of respiratory diseases, since it has systemic effects on many processes, such as inflammation, oxidative stress, smooth muscle and vascular tone in the airways. The correction of NO production can be used to specifically influence on the inflammatory response and prevent of the diseases progression.

\section{Conclusion}

Thus, a complex of disturbances in the regulation of intra- and intercellular signaling underlie systemic inflammatory process that determines a number of pathophysiological changes in chronic respiratory diseases. The disturbances include: the activation of various effector cells contributing to the development of different types of immune response, the modification of FA profile in the lipid membrane that lead to a change in its properties and an increase in the synthesis of pro-inflammatory eicosanoids, a change in CB2 receptor expression accompanied by an imbalance in cytokine production. Althought COPD and asthma have a different etiopathogenesis, there is a generality of immune disorders and regulatory mechanisms of systemic inflammation in the diseases. Both COPD and asthma is characterised by multi-type Th immune responses, the nature of which depends on severity or control of the disease. Mixed phenotypes apper and are followed by the formation of Th17 type of immune response associated with a worsening of both COPD and asthma. Common mechanisms of maintenance of systemic inflammation in the diseases include hyperproduction of cytotoxic eicosanoids, decreased expression of CB2 receptors, the formation of mitochondrial dysfunction due to violations of FA composition of the organelle, increased NO synthesis. Understanding these mechanisms will allow developing medical technologies for the selective regulation of chronic inflammation, which limit the destructive effects of inflammatory mediators.

\section{Conflict of interest}

We declare that we have no conflict of interest.

\section{References}

1. Global Strategy for Diagnosis, Management, and Prevention of COPD 2016. Global Initiative for Chronic Obstructive Lung Disease (GOLD), 2016. https://goldcopd.org/global-strategy-diagnosis-managementprevention-copd-2016/.

2. Global strategy for asthma management and prevention. Global Initiative for Asthma (GINA), 2016; 89 p. https://ginasthma.org/wpcontent/uploads/2016/04/GINA-Appendix-2016-final.pdf.

3. Eapen MS, Sohal SS. Understanding novel mechanisms of microbial pathogenesis in chronic lung disease: implications for new therapeutic targets. Clin Sci 2018; 132(3): 375-379. http://doi.org/10.1042/CS20171261. 
4. Chereshnev VA, Gusev EYu. Immunological and Pathophysiological mechanisms of Systemic Inflammation. Med Immunol 2012; 14(1-2): 920. Russian. https://elibrary.ru/item.asp?id=17332368.

5. Zotova NV, Chereshnev VA, Gusev EY. Systemic inflammation: methodological approaches to identification of the common pathological process. PLoS One 2016; 11(5): e0155138. https://doi.org/10.1371/journal.pone.0155138.

6. Hattab Y, Alhassan S, Balaan M, Lega M, Singh AC. Chronic Obstructive Pulmonary Disease. Crit Care Nurs Q 2016; 39(2): 124-130. http://doi.org/10.1097/CNQ.0000000000000105

7. Arita M. Mediator lipidomics in acute inflammation and resolution. $J$ Biochem 2012; 152(4): 313-319. https://doi.org/10.1093/jb/mvs092.

8. Battista N, Di Tommaso M, Bari M, Maccarrone $M$. The endocannabinoid system: an overview. Front Behav Neurosci 2012; 6: 9. https://doi.org/10.3389/fnbeh.2012.00009.

9. Calder PC. n-3 fatty acids, inflammation and immunity: new mechanisms to explain old actions. Proc Nutr Soc 2013; 72(3): 326-336. http://doi.org/10.1017/S0029665113001031.

10. Buckley CD, Gilroy DW, Serhan CN. Proresolving Lipid Mediators and Mechanisms in the Resolution of Acute Inflammation. Immunity 2014; 40(3): 315-327. http://doi.org/10.1016/i.immuni.2014.02.009.

11. Miyata J, Arita M. Role of omega-3 fatty acids and their metabolites in asthma and allergic diseases. Allergol Int 2015; 64(1): 27-34. https://doi.org/10.1016/i.alit.2014.08.003.

12. Gerasimenko ND. Lipids, Inflammation and Pathology: the Role of the Peroxisome Proliferator-Activated Receptors. Bulletin of problems biology and medicine 2015; 2(1): 10-15. Russian. https://elibrary.ru/item.asp?id=24330576.

13. Karateev $\mathrm{AE}$, Aleinikova TL. Eicosanoids and inflammation. Modern Rheumatology Journal 2016; 10(4): 73-86. Russian. http://doi.org/10.14412/1996-7012-2016-4-73-86.

14. Karaman YK, Lobanova EG. Endocannabinoids and eicosamoids: biosynthesis and interactions with immune response. Med Immunol 2013; 15(2): 119-130. Russian. https://doi.org/10.15789/1563-06252013-2-119-130.

15. Márquez L, Abanades S, Andreu M. Endocannabinoid system and bowel inflammation. Med Clin (Barc) 2008; 131(13): 513-517. http://doi.org/10.1016/j.molmed.2012.07.009.

16. Kalinina EP, Lobanova EG, Antonyuk MV. Immune and metabolic phenotypes of chronic obstructive pulmonary disease in men. Med Immunol 2014; 16(4): 375-380. Russian. https://doi.org/10.15789/1563-0625-2014-4-375-380.

17. Vitkina TI, Sidletskaya KA, Mineeva EE. The changes of serum level of IL-4 and expression of its receptor on T-helpers of peripheral blood of patients with chronic obstructive pulmonary disease. Health Med Ecol Sci 2017; 71(4): 40-44. Russian. https://doi.org/10.5281/zenodo.835314.

18. Nikonova MF, Donetskova AD, Sidorovich OI, Luss LV, Yarilin AA. Peculiarities of expression of the genes encoding for transcription factors controlling differentiation of adaptive CD4+ T-lymphocyte subpopulations in allergy. Immunology 2011; 32(4): 189-191. Russian. https://elibrary.ru/item.asp?id=16921331.

19. Zhu J, Yamane H, Paul WE. Differentiation of effector CD4 T cell populations. Annu Rev Immunol 2010; 28: 445-489. http://doi.org/10.1146/annurev-immunol-030409-101212.

20. Lobanova EG, Kalinina EP, Denisenko YK, Antonuk MV. Role of deviation subpopulation of T-helper 17 type in chronic obstructive pulmonary disease. International Journal of Applied and Fundamental Research 2015; (11-2): 216-219. Russian. https://elibrary.ru/item.asp?id=24311880.

21. Vitkina TI, Denisenko YuK, Davydova KA. The changes in the profile of cytokines in progressing chronic obstructive pulmonary disease. Int Res J 2016; 49(7-3): 6-8. Russian. http://doi.org/10.18454/IRJ.2016.49.024.
22. Lobanova EG, Kalinina EP, Denisenko YuK. Cytokine contents in Th1and Th17-type lymphocytes in chronic obstructive pulmonary disease. Med Immunol 2016; 18(3): 287-290. Russian. http://doi.org/10.15789/1563-0625-2016-3-287-290.

23. Rincon $M$, Irvin C. Role of IL- 6 in asthma and other inflammatory pulmonary diseases. Int J Biol Sci 2012; 8(9): 1281-1290. http://doi.org/10.7150/ijbs.4874.

24. Scheller J, Ohnesorge N, Rose-John S. Interleukin-6 trans-signalling in chronic inflammation and cancer. Scand J Immunol 2006; 63(5): 321 329. https://doi.org/10.1111/j.1365-3083.2006.01750.x.

25. Dienz O, Rincon M. The effects of IL-6 on CD4 T cell responses. Clin Immunol 2009; 130(1): 27-33. http://doi.org/10.1016/j.clim.2008.08.018.

26. Vitkina TI, Denisenko YuK, Novgorodtseva TP, Sidletskaya KA Expression of IL-6 receptor in patients with chronic obstructive pulmonary disease of varying severity. Russian Allergology Journal 2017; 14(S1): 134-136. https://elibrary.ru/item.asp?id=36409885 Russian.

27. Vitkina TI, Denisenko YuK, Sidletskaya KA. Changes in the surface IL-6 receptor expression of distinct immune cells in progression of chronic obstructive pulmonary disease. Med Immunol 2017; 19(2): 191-196. Russian. https://doi.org/10.15789/1563-0625-2017-2-191-196.

28. Moldaver DM, Larché $M$, Rudulier CD. An Update on Lymphocyte Subtypes in Asthma and Airway Disease. Chest 2017; 151(5): 1122 1130. http://doi.org/10.1016/j.chest.2016.10.038.

29. Tsareva UV, Demeev JA, Antonyuk MV. Cytokine balance in patients with bronchial asthma with obesity. East Eur Sci J 2016. 8(2): 110-112. Russian. https://elibrary.ru/item.asp?id=28082801

30. Kalinina EP, Denisenko YK, Vitkina TI, Lobanova EG, Novgorodtseva TP Antonyuk MV, et al. The mechanisms of the regulation of immune response in patients with comorbidity of chronic obstructive pulmonary disease and asthma. Can Respir J 2016; 2016: 4503267. https://doi.org/10.1155/2016/4503267.

31. Barabash EY, Kalinina EP, Gvozdenko TA, Denisenko YK, Novgorodtseva $\mathrm{TP}$, Antonyuk MV, et al. Regulation of immune response of patients with partially controlled vs controlled bronchial asthma. Med Immuno 2017; 19(1): 65-72. Russian. http://doi.org/10.15789/1563-0625-20171-65-72.

32. Giudetti AM, Cagnazzo R. Beneficial effects of n-3 PUFA on chronic airway inflammatory diseases. Prostaglandins Other Lipid Mediat 2012; 99(3-4): 57-67. https://doi.org/10.1016/j.prostaglandins.2012.09.006.

33. Serhan CN, Chiang $N$. Resolution phase lipid mediators of inflammation: agonists of resolution. Curr Opin Pharmacol 2013; 13(4): 632-640. http://doi.org/10.1016/j.coph.2013.05.012.

34. Karaman YuK, Lobanova EG, Yubitskaya NS. Disturbance of eicosanoid synthesis in patients with metabolic syndrome. Klinicheskaia Meditsina 2010; 88(3): 46-49. Russian. https://elibrary.ru/item.asp?id=15138370.

35. Novgorodtseva TP, Karaman YK, Zhukova NV, Lobanova EG, Antonyuk $\mathrm{MV}$, Kantur TA. Composition of fatty acids in plasma and erythrocytes and eicosanoids level in patients with metabolic syndrome. Lipids Health Dis 2011; 10: 82. http://doi.org/10.1186/1476-511X-10-82.

36. Novgorodtseva TP, Denisenko YK, Zhukova NV, Antonyuk MV, Knyshova VV, Gvozdenko TA. Modification of the fatty acid composition of the erythrocyte membrane in patients with chronic respiratory diseases. Lipids Health Dis 2013; 12: 117. http://doi.org/10.1186/1476-511X-12-117.

37. Novgorodtseva TP, Karaman YuK, Antonyuk MV, Knyshova VV, Zhukova NV. Relationship of modification of fatty acid formation with systemic inflammation in asthma and chronic obstructive pulmonary disease. Bulletin Physiology and Pathology of Respiration 2013; (49): 16-23. Russian. https://elibrary.ru/item.asp?id=20273118.

38. Denisenko YK, Novgorodtseva TP, Zhukova NV, Lobanova NG, Antonuk MV. Metabolic conversion of polyunsaturated fatty acids in chronic inflammatory respiratory diseases. International Journal of Applied and 
Fundamental Research 2015; (11-2): 201-206. Russian. https://elibrary.ru/item.asp?id=24311877.

39. Denisenko YK, Novgorodtseva TP, Zhukova NV, Antonuk MV, Lobanova EG Kalinina EP. Association of fatty acid metabolism with systemic inflammatory response in chronic respiratory diseases. Biomed Khim 2016; 62(3): 341-347. Russian. http://doi.org/10.18097/PBMC20166203341.

40. Denisenko YuK, Vitkina TI, Novgorodtseva TP, Kondrat'eva EV, Zhukova NV, Borshchev PV. Fatty acid spectrum of mitochondrial thrombocytes membranes in patients with chronic non-obstructive bronchitis. Bulletin Physiology and Pathology of Respiration 2013; (50): 34-38. Russian. https://elibrary.ru/item.asp?id=20917682.

41. Denisenko YuK, Novgorodtseva TP, Kondrat'eva EV, Zhukova NV, Antonyuk MV, Knyshova VV, et al. Morpho-functional characteristics of blood cell mitochondria in bronchial asthma. Klinicheskaia Meditsina 2015; 93(10): 47-51. Russian. https://elibrary.ru/item.asp?id=24859605.

42. Denisenko YuK, Novgorodtseva TP, Vitkina TI, Antonyuk MV, Zhukova NV. Mitochondrial dysfunction in chronic obstructive pulmonary disease. Bulletin Physiology and Pathology of Respiration 2016; (60): 28-33. Russian. http://doi.org/10.12737/20048.

43. Denisenko YK, Novgorodtseva TP, Vitkina TI, Gvozdenko TA, Antonuk $\mathrm{MV}$, Khodosova KK. Fatty acid value in development mitochondrial dysfunction in asthma. International journal of applied and fundamental research 2016; (10-2): 205-209. https://elibrary.ru/item.asp?id=26699324. Russian.

44. Titov VN. The function of mitochondrion, carnitine, coenzyme-A, fat acids, glucose, the Randle cycle and insulin: A lecture. Russian Clinical Laboratory Diagnostics 2012; (2): 32-42. Russian. https://elibrary.ru/item.asp?id=17694109.

45. Lobanova EG. Role of endocannabinoid receptors in the immune response regulation. Med Immunol 2012; 14(3): 189-194. Russian. http://doi.org/10.15789/1563-0625-2012-3-189-194.

46. Di Marzo V, Matias I. Endocannabinoid control of food intake and energy balance. Nat Neurosci 2005; 8(5): 585-589. http://doi.org/10.1038/nn1457.

47. Console-Bram L, Marcu J, Abood ME. Cannabinoid receptors: nomenclature and pharmacological principles. Prog Neuropsychopharmacol Biol Psychiatry 2012; 38(1): 4-15. http://doi.org/10.1016/j.pnpbp.2012.02.009.

48. Denisenko YuK, Lobanova EG, Novgorodtseva TP, Gvozdenko TA, Nazarenko AV. The Role of Arachidonic Acid Metabolites (Endocannabinoids and Eicosanoids) in the Immune Processes: A Review. Int J Chem Biomed Sci 2015; 1(3): 70-78. http://www.aascit.org/journal/archive2?journalld=890\&paperld=2281.

49. Lobanova EG. The expression of circumferential endocannabinoid second type receptor on immunocompetent cells with activation of immune system in vivo. Bulletin Physiology and Pathology of Respiration 2012; (44): 55-61. https://elibrary.ru/item.asp?id=17766549.

50. Lobanova EG, Karaman YuK. The influence of ozonized physiological solution on the activity of endocannabinoid system. Medical Almanac 2013; 27(3): 72-73. Russian. https://elibrary.ru/item.asp?id=20523711.

51. Lobanova EG. Participation of the endocannabinoid system in the regulation of inflammatory processes. In: Trudy Instituta Meditsinskoy Klimatologii I Vosstanovitel'nogo Lecheniya Vladivostok. Vladivostok, Russia, 2014: 179-196. Russian. https://elibrary.ru/item.asp?id=22875472.

52. Lobanova EG, Karaman YuK, Borshchev PV, Gvozdenko TA. Expression of endocannabinoid $C_{2}$ receptor by immune cells at chronic obstructive pulmonary disease. Bulletin Physiology and Pathology of Respiration 2013; (47): 31-35. Russian. https://elibrary.ru/item.asp?id=18915706.

53. Lobanova EG. Influence of the cannabinoid receptors synthetic ligands on eicosanoids synthesis in vitro. The Bulletin of Siberian Branch of Russian Academy of Medical Sciences 2012; 32(2): 5-8. Russian. https://elibrary.ru/item.asp?id=17723577.
54. Malerba M, Radaeli A, Olivini A, Damiani G, Ragnoli B, Montuschi P, et al. Exhaled nitric oxide as a biomarker in COPD and related comorbidities. Biomed Res Int 2014; 2014: 271918. http://doi.org/10.1155/2014/271918.

55. Feng JX, Lin $Y$, Lin J, He SS, Chen MF, Wu XM, et al. Relationship between fractional exhaled nitric oxide level and efficacy of inhaled corticosteroid in asthma-COPD overlap syndrome patients with different disease severity. J Korean Med Sci 2017; 32(3): 439-447. http://doi.org/10.3346/ikms.2017.32.3.439.

56. Bocharova NV, Novgorodtseva TP. Level nitric oxide metabolites in the blood of patients with chronic respiratory diseases. Health Med Ecol Sci 2017; 71(4): 27-31. Russian. http://doi.org/10.5281/zenodo.835308.

\section{Authors:}

Tatyana P. Novgorodtseva - MD, DSc, Professor, Chief Researcher, Laboratory of Biomedical Research, Vladivostok Branch of Far Eastern Scientific Centre of Physiology and Pathology of Respiration, Institute of Medical Climatology and Rehabilitative Treatment, Vladivostok, Russia. https://orcid.org/0000-0002-6058-201X.

Tatyana A. Gvozdenko - MD, DSc, Professor, Chief Researcher, Laboratory of Rehabilitative Treatment, Vladivostok Branch of Far Eastern Scientific Centre of Physiology and Pathology of Respiration, Institute of Medical Climatology and Rehabilitative Treatment, Vladivostok, Russia. http://orcid.org/0000-0002-6413-9840.

Tatyana I. Vitkina - DSc, Professor, Leading Researcher, Laboratory of Biomedical Research, Vladivostok Branch of Far Eastern Scientific Centre of Physiology and Pathology of Respiration, Institute of Medical Climatology and Rehabilitative Treatment, Vladivostok, Russia. http://orcid.org/00000002-1009-9011.

Yuliya K. Denisenko - DSc, Head, Laboratory of Biomedical Research, Vladivostok Branch of Far Eastern Scientific Centre of Physiology and Pathology of Respiration, Institute of Medical Climatology and Rehabilitative Treatment, Vladivostok, Russia. http://orcid.org/0000-0003$\underline{4130-8899}$

Marina V. Antonyuk - MD, DSc, Professor, Head, Laboratory of Rehabilitative Treatment, Vladivostok Branch of Far Eastern Scientific Centre of Physiology and Pathology of Respiration, Institute of Medical Climatology and Rehabilitative Treatment, Vladivostok, Russia. https://orcid.org/0000-0002-2492-3198.

Vera V. Knyshova - MD, PhD, Senior Research, Laboratory of Rehabilitative Treatment, Vladivostok Branch of Far Eastern Scientific Centre of Physiology and Pathology of Respiration, Institute of Medical Climatology and Rehabilitative Treatment, Vladivostok, Russia. http://orcid.org/0000$\underline{0001-9086-7369}$ 